\title{
Small Heat Shock Proteins Can Confer Tolerance to Nanomaterial-induced Toxicity
}

\author{
Hanseul Park, Eunhye Ko, and Yeh-Jin Ahn' \\ Department of Life Science, College of Natural Sciences, Sangmyung \\ University, 20 Hongjimun 2-gil, Jongno-gu, Seoul 110-743, Korea
}

Additional index words. Daucus carota, gene expression, multiwalled carbon nanotube, silver nanoparticle, stress tolerance, surfactant

\begin{abstract}
The expression of a small heat shock protein (sHSP) in plants and its possible function in conditions related to nanomaterial exposure were examined. Multiwalled carbon nanotubes (MWCNTs) and silver nanoparticles (AgNPs) induced toxicity that was indicated by the bending and curling of carrot leaf tissues. Both nanomaterials induced the expression of a small heat shock protein in carrot, DcHsp17.7, but reduced the level of a constitutive heat shock cognate 70. To examine the possible function of DcHsp17.7, the coding gene was heterologously expressed in Escherichia coli. Both nanomaterials reduced the viability of $E$. coli cell lines. However, the transgenic cell line heterologously expressing DcHsp17.7 showed higher levels of cell viability, compared with vector controls, when exposed to MWCNTs and, more notably, to AgNPs. To the best of our knowledge, this is the first study reporting the influence of nanomaterials on the expression of a plant SHSP and its possible function in conferring tolerance to nanomaterial stress.
\end{abstract}

Engineered nanomaterials with at least one dimension between 1 and $100 \mathrm{~nm}$ are classified into two categories: fullerenes that include single-walled and multiwalled carbon nanotubes and inorganic nanoparticles that have two dimensions between 1 and $100 \mathrm{~nm}$ (Rico et al., 2011). They are widely used in more than 500 consumer products in industries such as food, communication, medicine, cosmetics, and agriculture and are estimated in the world market to reach $\$ 1$ trillion in 2015 (U.S. Environmental Protection Agency, 2014). In agriculture, nanomaterials are used in the form of fertilizers, herbicides, and pesticides for efficient delivery to promote plant growth (Pérez-de-Luque and Rubiales, 2009). As a result of their small sizes, nanomaterials easily pass through cellular membrane, translocate to various intracellular compartments, and associate with various biomolecules and cellular structures (reviewed in Nair et al., 2010).

Despite some advantages of using nanomaterials, there is an increasing number of recent studies reporting the possible cytoand genotoxicities of nanomaterials in

\footnotetext{
Received for publication 19 Feb. 2014. Accepted for publication 27 Apr. 2014.

This research was supported by the Business for Cooperative R \& D between Industry, Academy, and Research Institute funded by the Korea Small and Medium Business Administration in 2013 (C0150276) and by the Basic Science Research Program through the National Research Foundation of Korea (NRF) funded by the Ministry of Education (2012-0004406).

We thank Ms. Eunsun Jang for technical support. The anti-DcHsp17.7 was a kind gift from Prof. J. Lynn Zimmerman at Emory University.

${ }^{1}$ To whom reprint requests should be addressed; e-mail yjahn@smu.ac.kr.
}

living organisms. In humans, nanomaterials can cause toxicity in various organs such as lung, dermis, and liver (reviewed in Donaldson and Poland, 2012). They trigger oxidative stress, proinflammatory responses (Prasad et al., 2013), endoplasmic stress response, and apoptosis (Bouwmeester et al., 2011). Recent studies have reported that the accumulation of certain nanomaterials could also cause toxic effects on plants. For example, single-walled carbon nanotubes induced the accumulation of $\mathrm{H}_{2} \mathrm{O}_{2}$ and the expression of genes related to oxidative stress such as ascorbate peroxidase 1 and mitochondrial superoxide dismutase 1 (Shen et al., 2010). At the gene level, $\mathrm{CuO}$ in the form of nanoparticles caused mutagenic DNA lesions in radish (Raphanus sativus L.) and ryegrass (Lolium perenne L. and Lolium rigidum L.; Atha et al., 2011). The conflicting results on the effects of nanomaterials appear to be because of the experimental conditions used in the studies such as the characteristics of the nanomaterials (type, size, and concentration) and the plants (species and growth stages).

Heat shock proteins (HSPs) are a group of proteins that accumulate under heat and other various abiotic stresses. Small HSPs (12 to $42 \mathrm{kDa}$ in size) are unusually diverse in plants compared with other organisms. There are more than 30 sHSPs in plants (36 sHPs in Populous trichocarpa; Waters et al., 2008), which is the largest number in living organisms, suggesting that sHSPs probably play important roles in sessile plants. The model protein DcHsp17.7, a sHSP in carrot (Daucus carota L.), accumulates under various stress conditions such as heat (Malik et al., 1999), cold (Song and Ahn, 2010), salinity (Song and Ahn, 2011), oxidation, water shortage (Ahn and Song, 2012), and heavy metal stresses (Lee and Ahn, 2013). Furthermore, the transgenic E. coli heterologously expressing DcHsp17.7 showed a higher rate of survival compared with that of vector controls under these stresses, suggesting that DcHsp17.7 can confer tolerance to various abiotic stresses.

Carbon nanotubes are used to enhance germination of recalcitrant seeds. However, Tan and Fugetsu (2007) reported that MWCNTs caused aggregation of rice cell cultures. Furthermore, the nanomaterials also induced the expression of reactive oxygen species resulting in complete cell death in rice (Tan et al., 2009). Zucchini plants exposed to MWCNTs and AgNPs showed reduced biomass accumulation by $60 \%$ and $75 \%$, respectively (Stampoulis et al., 2009). AgNPs possess broad-spectrum antibacterial and antifungal properties, thus protecting plants from various diseases (Panáček et al., 2009). However, Kumari et al. (2009) observed chromatin bridge, stickiness, and a disrupted metaphase resulting in abnormal cell division in Allium cepa L. treated with AgNPs. Panda et al. (2011) also reported that AgNPs induced cell death and DNA damage in A. cepa L. Despite the possible phytotoxicity caused by nanomaterials, the changes in gene expression induced by nanomaterials and the tolerance mechanism in plants against nanomaterials are not completely understood. In this study, we examined the expression of DcHsp17.7 induced by nanomaterials such as MWCNTs and AgNPs. Furthermore, the possible function of DcHsp17.7 in conferring tolerance to nanotoxicity was also examined using a transgenic E. coli heterologously expressing DcHsp17.7. To the best of our knowledge, this is the first study reporting nanomaterial-induced accumulation of plant sHSP and its possible function in conferring tolerance to nanotoxicity.

\section{Materials and Methods}

Dispersion of nanomaterials. MWCNTs ( 6 to $9 \mathrm{~nm} \times 5 \mu \mathrm{m}$; diameter $=6.6 \mathrm{~nm}$ median $)$ and AgNPs (diameter of less than $100 \mathrm{~nm}$ ) from Sigma-aldrich (St. Louis, MO) were added to double-distilled water $(200 \mathrm{~mL}$ for $0.2 \mathrm{~g})$ containing Tween $20(0.05 \%)$; subsequently, ultrasonication $(420 \mathrm{~W}, 20 \mathrm{Khz}$, for a total of $30 \mathrm{~min}$; repeats of $10 \mathrm{~s}$ ultrasonication and 30-s pause) was performed using a Sonomasher (S \& T Science, Seoul, Korea). Stock solutions were diluted to the final concentration of $200 \mu \mathrm{g} \cdot \mathrm{mL}^{-1}$. After $5 \mathrm{~h}$, the appearance of suspension was documented by photographs.

Acute toxicity of nanomaterials on carrot leaf tissue. Carrot plants (Daucus carota L. cv. Mussangochon) were grown in a controlled environmental chamber $\left(19\right.$ to $21^{\circ} \mathrm{C}$, 8 to $16 \mathrm{~h}$, night-day) with light from a fluorescent lamp at an intensity of $200 \mu \mathrm{E} \cdot \mathrm{m}^{-2} \cdot \mathrm{s}^{-1}$ and a relative humidity of $60 \%$. Leaf tissues from 3- to 2-month-old carrot plants were placed in MWCNT (up to $200 \mu \mathrm{g} \cdot \mathrm{mL}^{-1}$ with $0.01 \%$ Tween 20; Khodakovskaya et al., 2011) and AgNP solutions (up to 200 $\mu \mathrm{g} \cdot \mathrm{mL}^{-1}$ with $0.01 \%$ Tween 20; Stampoulis 

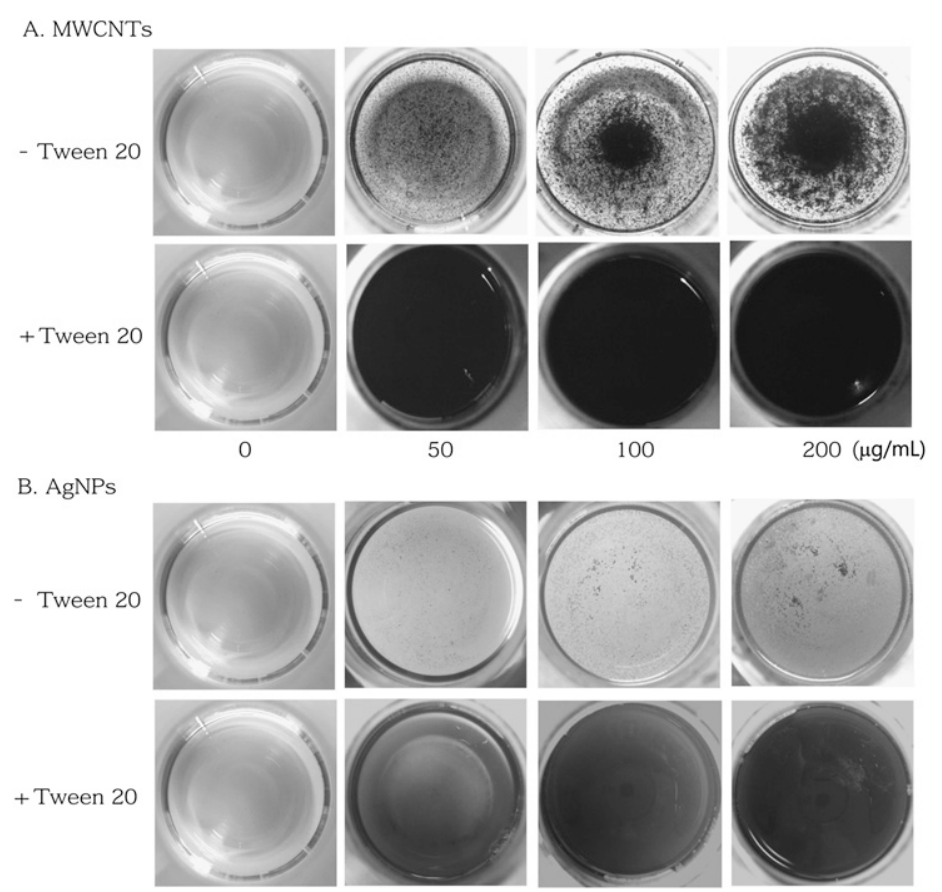

0

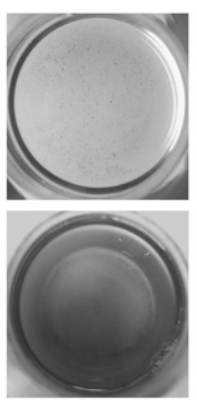

50

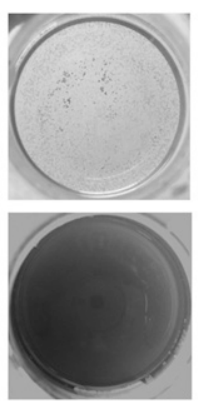

100

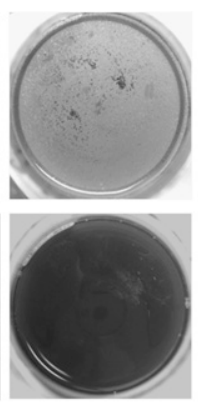

$200(\mu \mathrm{g} / \mathrm{mL})$

Fig. 1. Dispersion of nanomaterials by Tween 20. (A) Multiwalled carbon nanotubes (MWCNTs) and (B) silver nanoparticles (AgNPs; $0.2 \mathrm{~g}$ each) were added to double-distilled water (200 mL) containing $0.05 \%$ Tween 20 and subjected to ultrasonication for $30 \mathrm{~min}$. Resulting solutions were diluted with double-distilled water to specified concentrations in $200 \mathrm{~mL}$. After $5 \mathrm{~h}$, appearance of suspension was documented by photographs.

\section{A. MWCNTS}

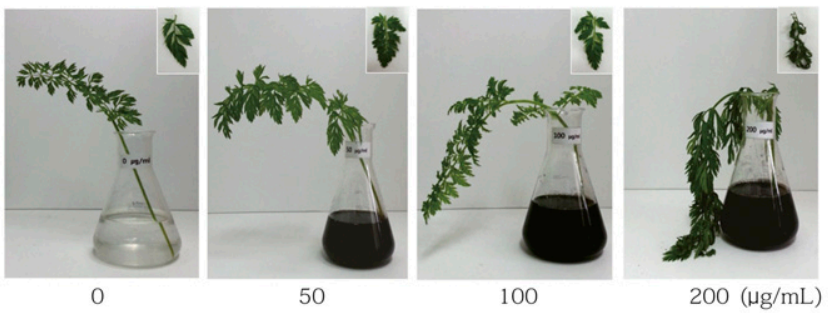

B. AgNPs

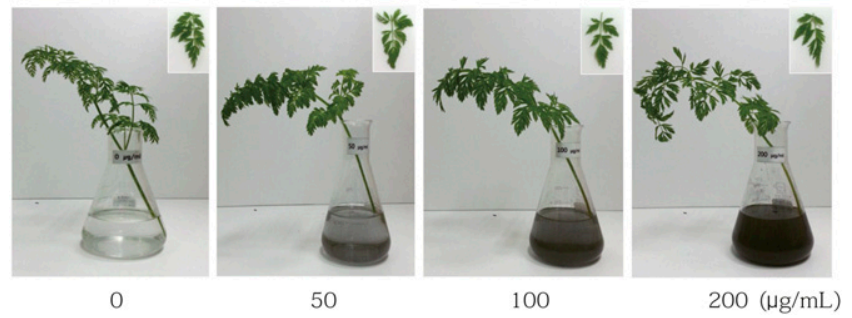

Fig. 2. Acute toxicity of nanomaterials on carrot leaf tissues. (A) Multiwalled carbon nanotubes (MWCNTs) and (B) silver nanoparticles (AgNPs) stock solutions (0.2 g in $200 \mathrm{~mL}$ double-distilled water containing $0.05 \%$ Tween 20 ) were prepared, as described previously. After dilution to specified concentrations with double-distilled water, leaf tissues from 2- to 3-month-old carrot plants were placed in the solution for $5 \mathrm{~h}$, and photographs were taken from the side.

et al., 2009) for $5 \mathrm{~h}$ and photographs were taken from the side. In addition, carrot leaf tissues were also placed in activated carbon and Ag powder (up to $200 \mu \mathrm{g} \cdot \mathrm{mL}^{-1}$ ), the corresponding controls for MWCNTs and AgNPs, for $5 \mathrm{~h}$ to examine if these non-nanosized controls cause acute toxicity.

Immunodetection of DcHsp17.7 accumulation induced by nanomaterials. Carrot leaf tissues treated with MWCNTs and AgNPs (up to $200 \mu \mathrm{g} \cdot \mathrm{mL}^{-1}$ with $0.01 \%$ Tween 20 for $5 \mathrm{~h}$ ) as described previously were immediately frozen in liquid nitrogen and stored at $-80{ }^{\circ} \mathrm{C}$ until analysis. To examine the accumulation of DcHsp17.7 induced by MWCNTs and AgNPs, proteins were extracted from carrot tissues, quantified by performing the Bradford assay (Bradford, 1976), and resolved by performing sodium dodecyl sulfate polyacrylamide gel electrophoresis (SDS-PAGE, $17 \%$ ) followed by immunoblot analysis using a polyclonal antibody raised against DcHsp17.7, as previously described (Ahn et al., 2004). Levels of a constitutive protein, which reacted to a polyclonal antibody raised against a recombinant heat shock cognate 70 in spinach (Enzo Life Sciences, Farmingdale, $\mathrm{NY}$ ), were also examined under the same conditions. The sizes of the protein bands were $\approx 18$ and $70 \mathrm{kDa}$ for the two antibodies, respectively. Coomassie staining showed the entire protein profile in the presence of nanomaterials at equal protein loading. Experiments were performed three times with two to three leaves per condition and representative images are shown.

Generation of transgenic E. coli heterologously expressing DcHsp 17.7. The DcHsp17.7 gene was inserted into pET11a vector using a previously described method (Kim and Ahn, 2009). Transformed E. coli BL21 (DE3) containing pET11a-DcHsp17.7 recombinant vector and vector control containing the unmodified pET11a expression vector were cultured overnight, diluted to 1 : 1000 with fresh Luria Broth (LB) medium containing ampicillin, and continuously incubated until the O.D. at $600 \mathrm{~nm}$ reached 0.6 . Then, isopropyl $\beta$-D-thiogalactopyranoside (IPTG) was added to a final concentration of $1 \mathrm{~mm}$ to induce heterologous expression of DcHsp 17.7. After $2 \mathrm{~h}$ of incubation, MWCNT and AgNP stock solutions (1 g. $\mathrm{L}^{-1}$ with $0.05 \%$ Tween 20), prepared as described previously, were added to the final concentration of $200 \mu \mathrm{g} \cdot \mathrm{mL}^{-1}$. After incubation for $5 \mathrm{~h}$, bacterial proteins were extracted using ultrasonication $(420 \mathrm{~W}, 20 \mathrm{Khz}$ for a total of $4 \mathrm{~min}$ and $40 \mathrm{~s}$; repeats of $10 \mathrm{~s}$ ultrasonication and $30 \mathrm{~s}$ pause; Lee and Ahn, 2013) and quantified by performing the Bradford assay (Bradford, 1976). Bacterial proteins (30 $\mu \mathrm{g}$ per lane) were subjected to SDS-PAGE (17\%) and immunoblot analysis using a polyclonal antibody raised against DcHsp17.7, as per a previously described method (Song and Ahn, 2011).

Bacterial cell viability in the presence of surfactants and nanomaterials. Overnight bacterial cell culture, dilution, and IPTG treatment $(2 \mathrm{~h})$ were performed for the transgenic cell line heterologously expressing DcHsp17.7 and vector control containing the unmodified pET11a expression vector, as described previously. To examine possible toxicity of surfactant, the two bacterial cell lines were cultured in $0.01 \%$ Tween 20 (El-Temsah and Joner, 2010) and SDS (Stampoulis et al., 2009). The stock solutions of activated carbon, Ag powder, MWCNTs, and AgNPs $(0.1 \mathrm{~g}$ in $200 \mathrm{~mL}$ double-distilled water with $0.05 \%$ Tween 20 ) were prepared using ultrasonication and added to the two bacterial cell lines to the final concentration of $100 \mu \mathrm{g} \cdot \mathrm{mL}^{-1}$. Then, all the cell lines were cultured for an additional $5 \mathrm{~h}$, diluted to 1 : $10^{-6}$, and plated on solid LB plates containing ampicillin. After an overnight incubation, the number of surviving colonies was counted and the rates of bacterial cell viability were 


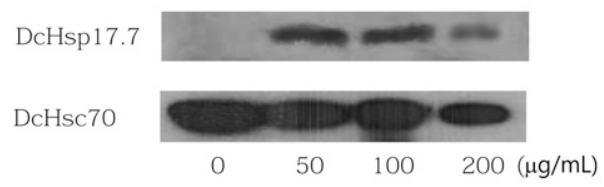

\section{A. MWCNTS}

\section{B. AgNPs}
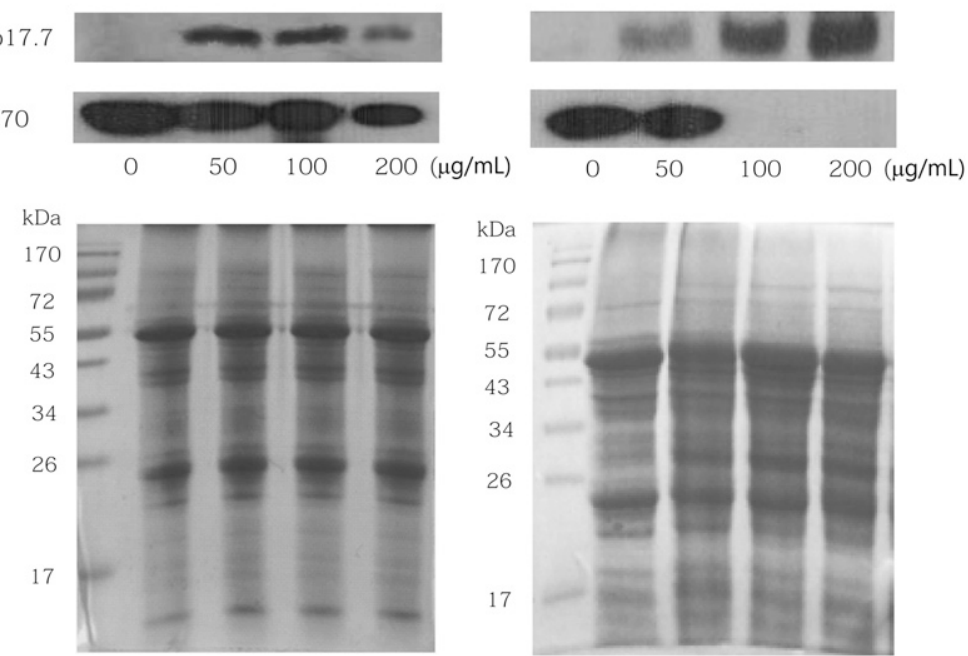

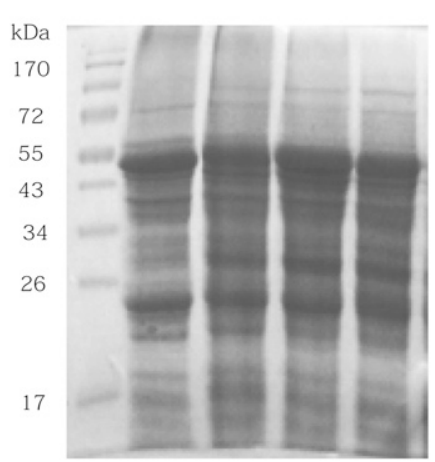

Fig. 3. Expression of DcHsp17.7 by nanomaterials. Carrot leaf tissues treated with (A) multiwalled carbon nanotubes (MWCNTs) and (B) silver nanoparticles (AgNPs; up to $200 \mu \mathrm{g} / \mathrm{mL}$ for $5 \mathrm{~h}$ ) were prepared as described previously. Then, proteins were extracted, quantified, and subjected to sodium dodecyl sulfate polyacrylamide gel electrophoresis (SDS-PAGE, 17\%) and immunoblot analysis using either a polyclonal antibody raised against DcHsp17.7 or a polyclonal antibody raised against spinach heat shock cognate (HSC) 70 . The size of the bands was $\approx 18$ and $70 \mathrm{kDa}$, respectively. Coomassie staining indicated equal loading of protein and overall protein profile in the presence of both nanomaterials.

\section{A. MWCNTs}

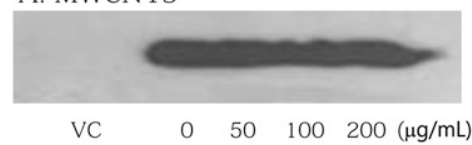

\section{B. AgNPs}

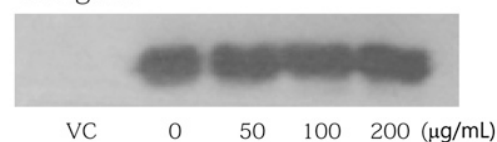

Fig. 4. Heterologous expression of DcHsp17.7 in Escherichia coli. The DcHsp17.7 gene was inserted into pET11a expression vector and introduced into $E$. coli BL21 (DE3). Overnight cell culture was performed, as described in the "Materials and Methods" section. After $2 \mathrm{~h}$ of isopropyl $\beta$-D-1-thiogalactopyranoside (IPTG) treatment, multiwalled carbon nanotube (MWCNT) and silver nanoparticle (AgNP) stock solutions $(0.2 \mathrm{~g}$ in $200 \mathrm{~mL}$ double-distilled water containing $0.05 \%$ Tween 20 ) were added to the final concentration of $200 \mu \mathrm{g} \cdot \mathrm{mL}^{-1}$, and bacterial cells were continuously cultured for $5 \mathrm{~h}$. Protein was extracted by performing ultrasonication, and $30 \mu \mathrm{g}$ of protein was subjected to sodium dodecyl sulfate polyacrylamide gel electrophoresis (SDS-PAGE, 17\%) followed by immunoblot analysis using a polyclonal antibody raised against DcHsp17.7. The size of the band was $\approx 18 \mathrm{kDa} . \mathrm{VC}=$ vector control containing the unmodified pET11a expression vector. calculated. A paired $t$ test was performed to compare the differences in cell viability between the transgenic cell line heterologously expressing DcHsp17.7 and the vector control containing the unmodified pET11a expression vector.

\section{Results and Discussion}

Dispersion of nanomaterials. When preparing test solutions containing nanomaterials, it is important to maintain them well suspended throughout the time course. In this study, Tween 20 (El-Temsah and Joner, 2010) was added to the test solutions containing MWCNTs and AgNPs, and ultrasonication was performed. Our results showed that Tween 20 effectively prevented the aggregation of the two nanomaterials (Fig. 1). In the absence of Tween 20, both the nanomaterials floated up on the surface of the test solutions at all the tested concentrations. Based on this observation, Tween 20 was used to prepare the test solutions containing MWCNTs and AgNPs in this study.

Acute toxicity of nanomaterials on carrot leaf tissue. To examine if the expression of DcHsp17.7 is induced by nanomaterials, carrot leaf tissues were placed in MWCNT and AgNP solutions (up to $200 \mu \mathrm{g} \cdot \mathrm{mL}^{-1}$ ). After $5 \mathrm{~h}$, all the tested leaves wilted and hung down, more severely in the presence of MWCNTs than that in the presence of AgNPs (Fig. 2), suggesting that nanomaterials can be toxic to plants. Adverse effects of nanomaterials on plants include reduction in germination, growth (seedlings, roots, and shoots), and biomass accumulation (reviewed in Rico et al., 2011). In addition, activated carbon and Ag powders, the corresponding controls for MWCNTs and AgNPs, did not cause any morphological changes at the same concentrations (data not shown).
A. Tween 20

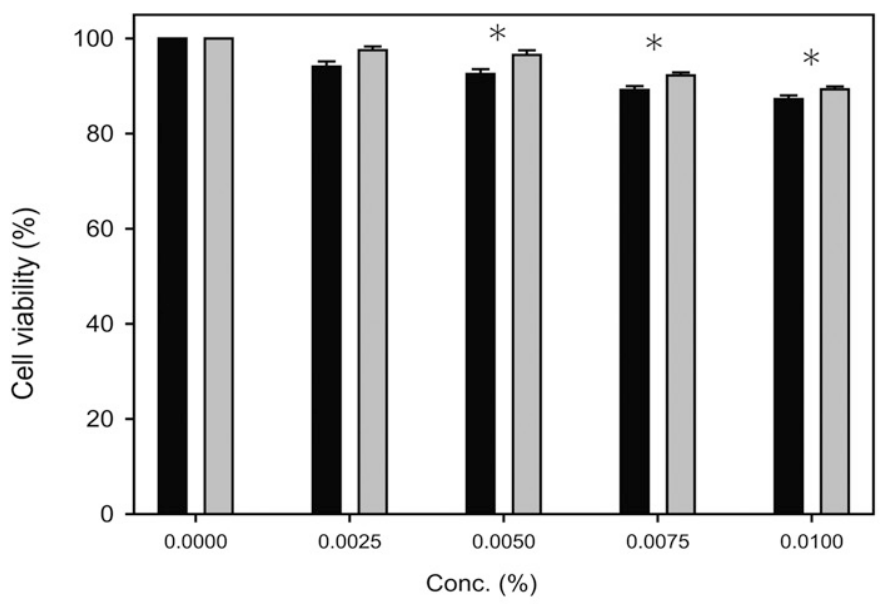

B. SDS

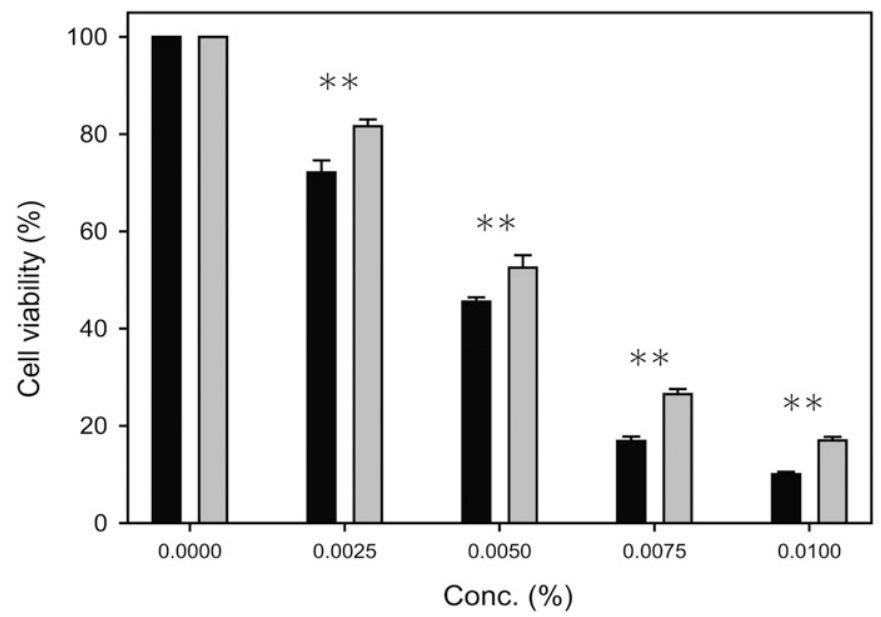

Fig. 5. Effects of surfactant on bacterial cell viability. Overnight cell culture was performed as described in the "Materials and Methods" section. After 2 h of isopropyl $\beta$-D-1-thiogalactopyranoside (IPTG) treatment, (A) Tween 20 and (B) sodium dodecyl sulfate (SDS) were added up to the final concentration of $0.01 \%$ and cultured at $37^{\circ} \mathrm{C}$ for $5 \mathrm{~h}$ with shaking. Then, the cells were diluted to $1: 10^{-6}$ and plated on solid Luria Broth (LB) plates containing ampicillin. After overnight incubation, the number of surviving colonies was counted, and the rates of cell viability were calculated. A paired $t$ test was performed to compare the differences in cell viability between the transgenic Escherichia coli heterologously expressing DcHsp17.7 and the vector control containing the unmodified pET11a expression vector $(* P<0.05$; $* * P<0.01)$. Black bars = vector control; gray bars = transgenic E. coli heterologously expressing DcHsp17.7. 

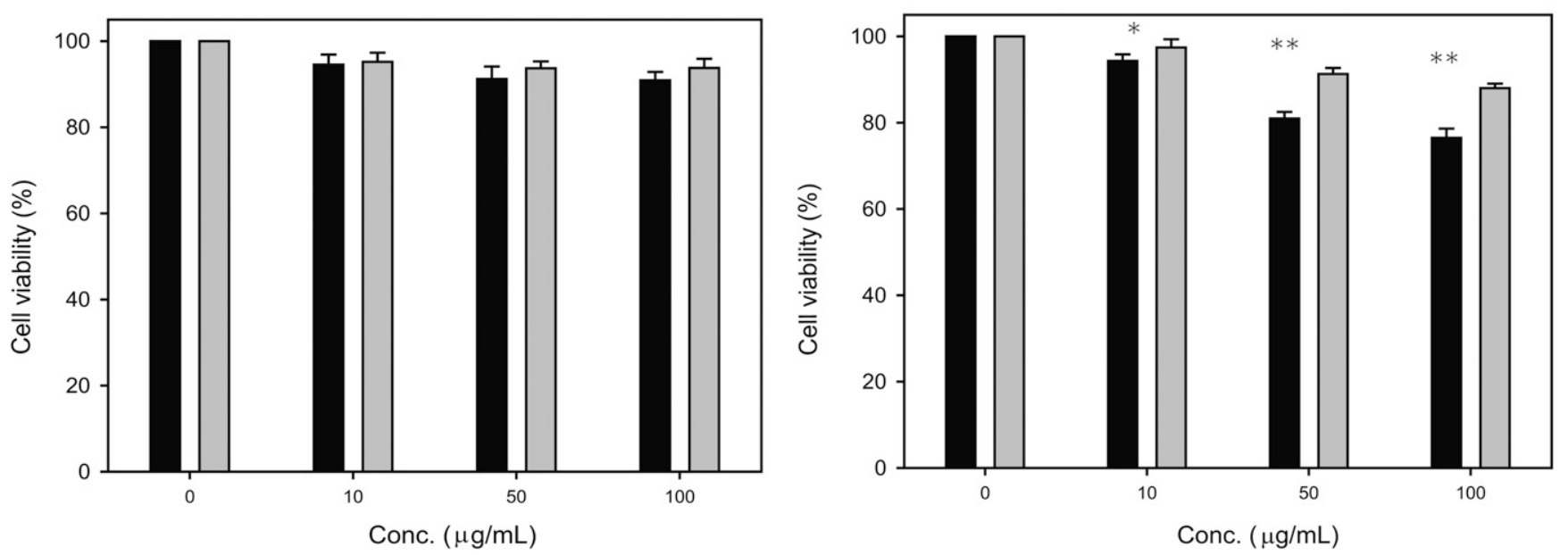

\section{MWCNTS}

D. AgNPs
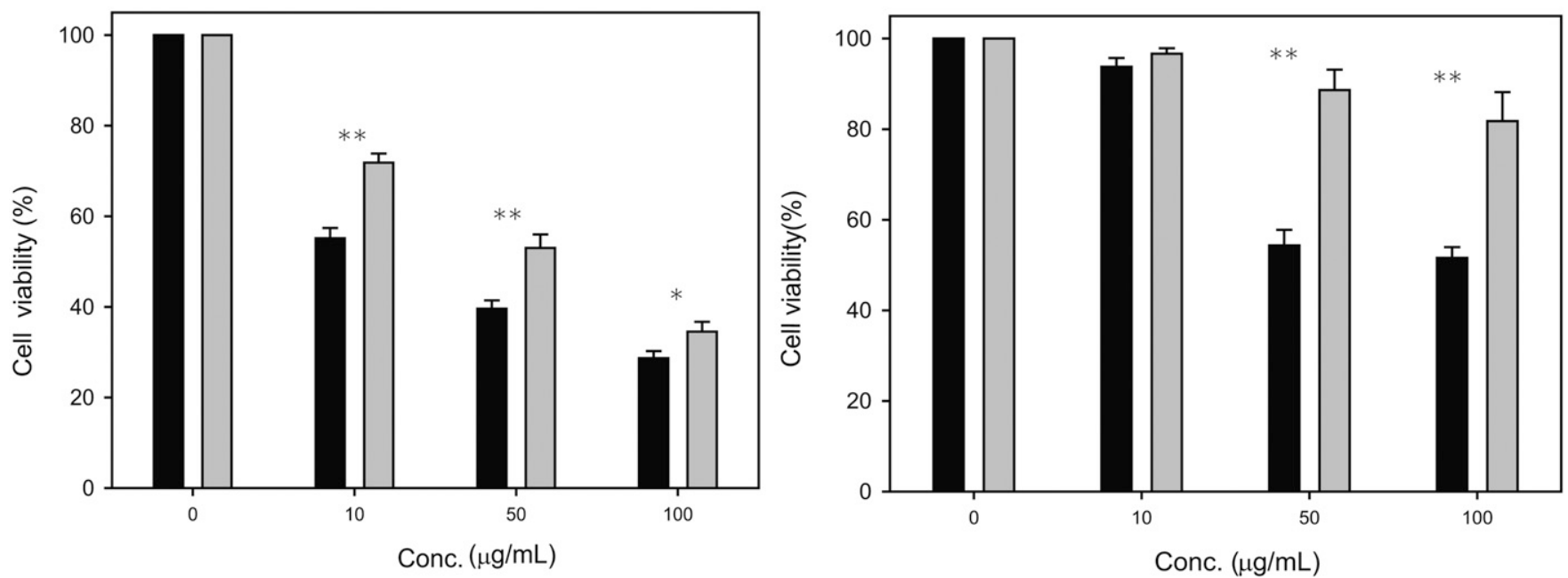

Fig. 6. Enhanced tolerance of cells heterologously expressing DcHsp17.7 to nanomaterials. Overnight cell culture was performed as described in the "Materials and Methods" section. After $2 \mathrm{~h}$ of isopropyl $\beta$-D-1-thiogalactopyranoside (IPTG) treatment, (A) activated carbon, (B) silver (Ag) powder, (C) multiwalled carbon nanotube (MWCNT), and (D) silver nanoparticle (AgNP) stock solutions were added to the final concentration of $100 \mu \mathrm{g} \cdot \mathrm{mL}^{-1}$. After $5 \mathrm{~h}$ incubation with shaking, the cells were diluted to $1: 10^{-6}$ and plated on a solid Luria Broth (LB) medium containing ampicillin. The number of surviving colonies was counted after overnight incubation at $37^{\circ} \mathrm{C}$, and the rates of survival were calculated. A paired $t$ test was performed to compare the differences in cell viability between the transgenic Escherichia coli heterologously expressing DcHsp17.7 and vector controls containing the unmodified pET11a expression vector $\left({ }^{*} P<0.05 ; * * P<0.01\right)$. Black bars $=$ vector control; gray bars = transgenic E. coli expressing DcHsp17.7.

Expression of DcHsp17.7 by MWCNTs and AgNPs. HSPs accumulate under various abiotic stresses such as heat, cold, salinity, drought, oxidation, and heavy metals (reviewed in Wang et al., 2004). They primarily function as molecular chaperones that prevent cellular proteins from denaturing and/or promote refolding of partially denatured proteins, resulting in increased cell viability under stress conditions. In this study, we examined the expression of DcHsp17.7, a small HSP in carrot, after treatment with MWCNTs and AgNPs. In the absence of stress, the protein was not expressed in the leaf tissue (Fig. 3). However, the nanomaterials triggered the expression of DcHsp17.7. In the presence of MWCNTs, the level of DcHsp17.7 increased and then decreased as the concentration of
MWCNTs increased (Fig. 3A). The level of the protein continuously increased in the presence of AgNPs (Fig. 3B). On the other hand, the level of heat shock cognate (HSC) 70, a cytosolic protein that is constitutively and ubiquitously expressed in most cells, gradually decreased as the concentration of MWCNT increased. In the presence of AgNPs, HSC70 rapidly disappeared at $100 \mu \mathrm{g} \cdot \mathrm{mL}^{-1}$ and above, suggesting that nanomaterials such as MWCNTs and AgNPs can inhibit the expression of housekeeping genes. Coomassie staining indicated that MWCNTs and AgNPs did not significantly affect the overall protein profile in carrot leaf tissue.

There are only a couple of studies reporting nanomaterial-induced HSP gene expression in plants. Cerium oxide $\left(\mathrm{CeO}_{2}\right)$ nanoparticles enhanced the accumulation of HSP70 in the roots of Zea mays L. (Zhao et al., 2012). At the gene level, Khodakovskaya et al. (2011) reported that MWCNTs induced the upregulation of stress-related genes in tomato (Solanum lycopersicum L.), including HSP90. These results indicate that some nanomaterials can trigger the expression of stress-related genes such as HSP genes. To the best of our knowledge, this is the first study reporting the nanomaterial-induced expression of a plant sHSP. Unlike large-molecular-weight HSPs, which require adenosine-5' -triphosphate (ATP) for their functions, the function of sHSPs is either unaffected or inhibited by ATP (Smýkal et al., 2000). Considering the fact that the level of ATP decreases under stress conditions, leaving large molecular HSPs less active, 
the function of sHSPs is likely to be very important, especially under prolonged and/or severe stress conditions.

Heterologous expression of DcHsp 17.7. To examine the function of DcHsp17.7 under conditions related to nanomaterial exposure, the coding region of the DcHsp17.7 gene was introduced into E. coli (BL21). Immunoblot analysis using a polyclonal antibody raised against DcHsp17.7 indicated that IPTG successfully induced the heterologous expression of DcHsp17.7 (Fig. 4). The level of the protein remained unchanged when exposed to MWCNTs and AgNPs. In our previous studies, the level of heterologously expressed DcHsp17.7 decreased under conditions of cold (Song and Ahn, 2010), salinity (Song and Ahn, 2011), oxidation (Ahn and Song, 2012), and in the presence of lead (Lee and Ahn, 2013). On the other hand, the level did not change during water shortage (Ahn and Song, 2012) and in the presence of arsenate (Lee and Ahn, 2013). Our results indicate that the stability of heterologously expressed DcHsp17.7 in transgenic E. coli depends on the type of abiotic stress applied to the bacterial cell.

Possible toxicity of surfactant on bacterial cell viability. The effect of surfactant on E. coli viability was examined. Tween 20 (up to $0.01 \%$ ) slightly decreased the viability of both cell lines, vector controls, and transgenic cell lines heterologously expressing DcHsp17.7 to $87 \%$ and $89 \%$, respectively (Fig. 5A). Another commonly used surfactant, SDS, dramatically decreased the bacterial cell viability of both the cell lines to lower than $20 \%$, thus exhibiting cytotoxicity (Fig. 5B). However, the transgenic cell lines heterologously expressing DcHsp17.7 showed higher levels of survival, compared with the vector controls, in the presence of both surfactants, suggesting that DcHsp17.7 can confer tolerance to toxicity induced by surfactants.

Enhanced tolerance of transgenic cells heterologously expressing DcHsp17.7 to nanomaterials. The viability of the transgenic cell lines heterologously expressing DcHsp17.7 and vector controls was examined in the presence of MWCNTs and AgNPs. Corresponding non-nanosized controls, activated carbon and Ag powder, were first added to the cell lines. Activated carbon slightly lowered the cell viability to $\approx 90 \%$ (Fig. 6A) with no significant difference in the cell viability between the transgenic and vector control cell lines. Ag powder reduced the cell viability to $76 \%$ and $88 \%$ in the vector controls and transgenic cell lines heterologously expressing DcHsp17.7, respectively (Fig. 6B), indicating that $\mathrm{Ag}$ is toxic to $E$. coli.

MWCNTs and AgNPs further reduced bacterial cell viability (Fig. 6C-D). MWCNTs lowered the survival rate to $29 \%$ and $35 \%$ in the vector controls and transgenic cell lines heterologously expressing DcHsp17.7, respectively. AgNPs lowered the survival rate to $52 \%$ and $82 \%$ for the two cell lines, respectively. Our results indicate that MWCNTs are relatively more cytotoxic than AgNPs toward the bacterial cells. However, the heterologously expressed DcHsp17.7 can confer tolerance against both nanomaterials in transgenic E. coli. Considering the fact that the level of the heterologously expressed DcHsp17.7 did not change with MWCNTs (Fig. 4), the reduced viability of the transgenic cell lines expressing DcHsp17.7 with MWCNTs was probably not the result of the degradation of the protein. It is possible that the function of DcHsp17.7 is inhibited by MWCNTs. To the best of our knowledge, this is the first study reporting that a sHSP can provide protection against nanotoxicity.

Considering the increase in the accumulation of nanomaterials in our environments, understanding their actions and tolerance mechanisms in living organisms is very important to reduce possible toxicity of nanomaterials. The results of this study suggest that plant sHSPs can be expressed and that they can play a role in reducing the toxic effects of nanomaterials. Through genetic engineering, useful gene(s) can be introduced into plants and other organisms to confer tolerance against nanotoxicity. Further studies are required to examine the mechanism underlying the expression and function of HSPs under conditions related to nanomaterial exposures.

\section{Literature Cited}

Ahn, Y.-J., K. Claussen, and J.L. Zimmerman. 2004. Genotypic differences in the heat shock response and thermotolerance in four potato cultivars. Plant Sci. 166:901-911.

Ahn, Y.-J. and N. Song. 2012. A cytosolic heat shock protein expressed in carrot (Daucus carota L.) enhances cell viability under oxidative and osmotic stress conditions. HortScience 47:143-148.

Atha, D.H., H. Wang, E.J. Petersen, D. Cleveland, R.D. Holbrook, P. Jaruga, M. Dizdaroglu, B. Xing, and B.C. Nelson. 2011. Copper oxide nanoparticle mediated DNA damage in terrestrial plant models. Environ. Sci. Technol. 46:1819-1827.

Bouwmeester, H., J. Poortman, R.J. Peters, E. Wijma, E. Kramer, S. Makama, K. Puspitaninganindita, H.J. Marvin, A.A. Peijnenburg, and P.J. Hendriksen. 2011. Characterization of translocation of silver nanoparticles and effects on whole-genome gene expression using an in vitro intestinal epithelium coculture model. ACS Nano 5:4091-4103.

Bradford, M.M. 1976. A rapid and sensitive method for the quantitation of microgram quantities of protein utilizing the principle of protein-dye binding. Anal. Biochem. 72:248254.

Donaldson, K. and C.A. Poland. 2012. Inhaled nanoparticles and lung cancer-What we can learn from conventional particle toxicology. Swiss Med. Wkly. 142:w13547.

El-Temsah, Y.S. and E.J. Joner. 2010. Impact of Fe and $\mathrm{Ag}$ nanoparticles on seed germination and differences in bioavailability during exposure in aqueous suspension and soil. Environ. Toxicol. 27:42-49.

Khodakovskaya, M.V., K. de Silva, D.A. Nedosekin, E. Dervishi, A.S. Biris, E.V. Shashkov, E.I. Galanzha, and V.P. Zharov. 2011. Complex genetic, photothermal, and photoacoustic analysis of nanoparticle-plant interactions. Proc. Natl. Acad. Sci. USA 108:1028-1033.

Kim, H. and Y.-J. Ahn. 2009. Expression of a gene encoding the carrot HSP17. 7 in Escherichia coli enhances cell viability and protein solubility under heat stress. HortScience 44:866-869.

Kumari, M., A. Mukherjee, and N. Chandrasekaran. 2009. Genotoxicity of silver nanoparticles in Allinum cepa. Sci. Total Environ. 407:52435246.

Lee, J. and Y.-J. Ahn. 2013. Heterologous expression of a carrot small heat shock protein increased Escherichia coli viability under lead and arsenic stresses. HortScience 48:13231326.

Malik, M.K., J.P. Slovin, C.H. Hwang, and J.L. Zimmerman. 1999. Modified expression of a carrot small heat shock protein gene, Hsp17. 7 , results in increased or decreased thermotolerance. Plant J. 20:89-99.

Nair, R., S.H. Varghese, B.G. Nair, T. Maekawa, Y. Yoshida, and D.S. Kumar. 2010. Nanoparticulate material delivery to plants. Plant Sci. 179:154-163.

Panáček, A., M. Koláŕ, R. Večeřová, R. Prucek, J. Soukupová, V. Kryštof, P. Hamal, R. Zbořil, and L. Kvítek. 2009. Antifungal activity of silver nanoparticles against Candida spp. Biomaterials 30:6333-6340.

Panda, K.K., V.M.M. Achary, R. Krishnaveni, B.K. Padhi, S.N. Sarangi, S.N. Sahu, and B.B. Panda. 2011. In vitro biosynthesis and genotoxicity bioassay of silver nanoparticles using plants. Toxicol. In Vitro 25:1097-1105.

Pérez-de-Luque, A. and D. Rubiales. 2009. Nanotechnology for parasitic plant control. Pest Mgt. Sci. 65:540-545.

Prasad, R.Y., J.K. McGee, M.G. Killius, D.A. Suarez, C.F. Blackman, D.M. DeMarini, and S.O. Simmons. 2013. Investigating oxidative stress and inflammatory responses elicited by silver nanoparticles using high-throughput reporter genes in HepG2 cells: Effect of size, surface coating, and intracellular uptake. Toxicol. In Vitro 27:2013-2021.

Rico, C.M., S. Majumdar, M. Duarte-Gardea, J.R. Peralta-Videa, and J.L. Gardea-Torresdey. 2011. Interaction of nanoparticles with edible plants and their possible implications in the food chain. J. Agr. Food Chem. 59:3485-3498.

Shen, C., Q. Zhang, J. Li, F. Bi, and N. Yao. 2010. Induction of programmed cell death in Arabidopsis and rice by single-wall carbon nanotubes. Amer. J. Bot. 97:1602-1609.

Smýkal, P., J. Masín, I. Hrdý, I. Konopásek, and V. Zárský. 2000. Chaperone activity of tobacco HSP18, a small heat-shock protein, is inhibited by ATP. Plant J. 23:703-713.

Song, N. and Y.-J. Ahn. 2010. DcHsp17.7, a small heat shock protein from carrot, is upregulated under cold stress and enhances cold tolerance by functioning as a molecular chaperone. HortScience 45:469-474.

Song, N. and Y.-J. Ahn. 2011. DcHsp17. 7, a small heat shock protein in carrot, is tissuespecifically expressed under salt stress and confers tolerance to salinity. New Biotechnol. 28:698-704.

Stampoulis, D., S.K. Sinha, and J.C. White. 2009. Assay-dependent phytotoxicity of nanoparticles to plants. Environ. Sci. Technol. 43:9473-9479.

Tan, X. and B. Fugetsu. 2007. Multi-walled carbon nanotubes interact with cultured rice cells: Evidence of a self-defense response. J. Biomed. Nanotechnol. 3:285-288. 
Tan, X., C. Lin, and B. Fugetsu. 2009. Studies on toxicity of multi-walled carbon nanotubes on suspension rice cells. Carbon 47:3479-3487.

U.S. Environmental Protection Agency. 2014. Nanotechnology and nanomaterials research. Nanomaterials EPA is assessing. 10 Jan. 2014. $<\mathrm{http}$ //www.epa.gov/nanoscience/quickfinder/ nanomaterials.htm>.
Wang, W., B. Vinocur, O. Shoseyov, and A. Altman. 2004. Role of plant heat-shock proteins and molecular chaperones in the abiotic stress response. Trends Plant Sci. 9:244-252.

Waters, E.R., B.D. Aevermann, and Z. SandersReed. 2008. Comparative analysis of the small heat shock proteins in three angiosperm genomes identifies new subfamilies and reveals diverse evolutionary patterns. Cell Stress Chaperones 13:127-142.

Zhao, L., B. Peng, J.A. Hernandez-Viezcas, C. Rico, Y. Sun, J.R. Peralta-Videa, X. Tang, G. Niu, L. Jin, and A. Varela-Ramirez. 2012 Stress response and tolerance of Zea mays to $\mathrm{CeO}_{2}$ nanoparticles: Cross talk among $\mathrm{H}_{2} \mathrm{O}_{2}$, heat shock protein, and lipid peroxidation. ACS Nano 6:9615-9622. 